KINETIK, Vol. 2, No. 1, Februari 2017, Hal. 27-36

ISSN : 2503-2259,

E-ISSN : 2503-2267

\title{
Perancangan Generator 100 Watt Menggunakan Software Elektromagnetik Infolityca
}

\author{
M. Choirul Anam ${ }^{*}$, Nurhadi ${ }^{2}$, M. Irfan ${ }^{3}$ \\ 1,2,3 Universitas Muhammadiyah Malang \\ scout.yung1334@gmail.com*1, Nurhadi_ft@umm.ac.id ${ }^{2}$, irfan_tsd@yahoo.com ${ }^{3}$
}

\begin{abstract}
Abstrak
Perancangan generator menggunakan software merupakan hal yang sangat dibutuhkan sebelum melakukan pembuatan generator karena mampu menyimulasikan diameter, material, ketebalan, jumlah lilitan dan kecepatan putar generator sehingga nantinya ketika melakukan pembuatan generator bisa mencapai tingkat keberhasilan yang tinggi. Para peneliti sebelumnya ketika membuat generator langsung melakukan pembuatan tanpa ada simulasi terlebih dahulu sehingga hasil yang dicapi masih kurang dari target yang diinginkan. Software elektromagnetik infolityca merupakan software yang mampu menyimulasi motor dan generator. Software infolityca merupakan software yang berbasis Fenite Element Method (FEM) atau metode pembagian tak hingga. Adapun generator yang dirancang tipe radial fluks dengan jumlah 12 slot 8 pole, diameter 13 centimeter, ketebalannya 5 centimeter serta menggunakan 12 lilitan diputar dengan $100 \mathrm{rpm}$ dan frekuensi 66,6667 Hz. Didapatkan hasil dari rancangan generator tanpa beban tegangan output sebesar 21,65 volt, arus sebesar 0 ampere dan untuk rancangan generator beban didapatkan output tegangan sebesar 23,89, arusnya sebesar 5 Ampere.
\end{abstract}

Kata kunci: Generator 100 watt, Fenite Element Method, Infolityca, Perancangan Generator

\begin{abstract}
Designing the generator using software before making its physical form is compulsory because it is necessary to simulate the diameter, materials, tickness, windings, and the spinning speed in order to reach its best performance. Some previous researchers skipped the simulation process, thus resulting the generator they made cannot reach the expected target. Infolityca electromagnetic software is a software created to simulate motor and generator. This software is using Fenite Element Method (FEM). The type of the generator is radial flux 12 slots of 8 pole, diameter $13 \mathrm{~cm}$, thickness $5 \mathrm{~cm}$, and 12 windings rotated for $100 \mathrm{rpm}$ and frequency $66,6667 \mathrm{~Hz}$. From this simulation, it is found that the generator without load resulted output voltage up to 21.65 volt and the current is 0 Ampere, while the generator with load resulted output voltage up tp 21.65 volt, and the current is 5 Ampere.
\end{abstract}

Keywords: Generator 100 watt, Fenite Element Method, Infolityca, Design Generator

\section{Pendahuluan}

Perkembangan teknologi generator dari tahun ke tahun terus mengalami peningkatan mulai dari bentuk, desain, ukuran, material yang digunakan serta mengalami peningkatan efisiensi daya output dari generator tersebut. Perkembangan teknologi generator ini tidak lepas dengan adanya software untuk mendesain mesin-mesin listrik. Sehingga sebelum melakukan perancangan dan implementasi pembuatan mesin-mesin listrik khususnya generator, diharapkan nantinya mampu penelitian selanjutnya mengetahui bahan apa saja yang dibutuhkan dalam perancangan generator tersebut.

Banyak penelitian sebelumnya menggunakan metode Trial and Error, khususnya penelitian dari Indonesia. Metode tersebut dengan kata lain langsung melakukan pengerjaan terhadap generator yang sudah didesain secara matematis. Generator tipe radial fluks (menggunakan core/inti) serta menggunakan kecepatan putar $180 \mathrm{rpm}$ dan menghasilkan daya 25 watt. Target daya yang diharapkan dari generator tersebut 100 watt, namun generator hanya mampu mengeluarkan daya 25 watt. Hal ini dikarenakan beberapa hal mulai dari segi desain stator dan rpm yang digunakan. 
Sedangkan penelitian lain yang dilakukan menghasilkan generator tipe radial fluks (menggunakan core/inti), bahan stator core akrilik pejal, dan bahan rotornya kayu, dengan kecepatan $500 \mathrm{rpm}$, tegangan yang didapatkan 48,86 V dan arus keluarannya 2,09 A serta daya total yang dihasilkan 154,57 dari target 200 watt [1].

Sehingga muncul sebuah gagasan untuk mendesain atau merancang generator dengan menggunakan bantuan software CAD untuk menggambar bentuk 2D dan software magnet untuk melakukan simulasi generator. Saat melakukan pembuatan ataupun perancangan generator sebenarnya mampu memiliki efisiensi yang baik serta hasil daya mampu mendekati target yang diinginkan.

Dalam melakukan perancangan generator menggunakan software elektromagnetik Infolityca banyak aspek yang perlu diperhatikan, baik sebelum melakukan perancangan ataupun ketika melakukan perancangan. Karena banyak parameter yang menggunakan persamaan dan perlu dilakukan perhitungan saat mendesain generator [2]-[7]. Lebar airgap merupakan salah satu parameter yang menggunakan persamaan karena airgap kedepannya akan mempengaruhi output dan kinerja dari generator tersebut

\section{Metode Penelitian}

Objek penelitian ini adalah merancang generator dengan menggunakan magnet permanen yang nantinya mampu menghasilkan daya 100 watt pada kecepatan $1000 \mathrm{rpm}$. Generator yang dirancang merupakan generator tipe radial fluks menggunakan 12 slot dan 8 pole, pada perancangan generator 100 watt dengan menggunakan software magnet Infolityca ada beberapa tahapan yang harus dilakukan sebagai berikut.

\subsection{Dasar Perancangan}

Dasar perancangan merupakan tahapan awal dalam melakukan perancangan generator, karena dasar perancangan merupakan sebagai pijakan dalam proses perancangan adapun beberapa hal yang perlu dilakukan dalam dasar perancangan.

\subsubsection{Pengumpulan Data}

Pengumpulan data merupakan tahapan dalam dasar perancangan generator, bertujuan untuk mencari informasi atau pengumpulan referensi yang tepat. Sehingga nantinya dalam perancangan generator tidak asal membuat, akan tetapi sumber rujukannya ada dan dapat dipertanggungjawabkan seperti katalog motor dan generator 100-200 watt yang telah ada di pasaran, serta mengumpulkan data dari hasil penelitian sebelumnya.

\subsubsection{Aplikasi Generator 100 watt}

Tahapan kedua dalam dasar perancangan adalah mencari informasi tentang mengaplikasikan generator 100 watt. Sehingga nantinya diameter, output tegangan, dan arus yang dirancang agar sesuai dengan kegunaannya. Kebanyakan generator 100 watt digunakan dalam pembangkit listrik skala micro dengan output tegangan mencapai 12-24 volt.

\subsubsection{Penentuan Dimensi}

Tahapan ketiga dalam dasar perancangan, yaitu menentukan dimensi. Karena dalam perancangan ini sangat mempengaruhi keluaran generator adalah dimensi dari stator, rotor, serta dimensi dari coil yang akan digunakan. Dimensi dari stator dan rotor akan mempengaruhi ouput tegangan, sedangkan diameter coil akan mempengaruhi berapa besar arus yang dialirkan.

\subsection{Gambar Desain.}

Gambar desain merupakan tahapan untuk menggambar bentuk geometri dari stator, rotor, slot, lebar airgap, serta menentukan tata letak magnet yang sesuai sehingga nantinya akan menghasilkan sinyal sinus soida yang baik. Gambar desain dapat dilakukan langsung menggunakan software magnet Infolityca maupun software CAD seperti solidwork, inventor maupun autocad. Akan tetapi dalam pendesainan bentuk dari stator, rotor, slot maupun tata letak magnet biasanya menggunakan software solidwork dan autocad karena tools yang digunakan untuk membentuk sudut-sudut yang sulit dapat dilakukan dengan menggunakan software tersebut, sedangkan mendesain menggunakan software magnet Infolityca secara langsung sulit dilakukan karena tools yang tersedia sangat terbatas adapun Gambar 1 merupakan desain generator menggunakan software solidwork. 


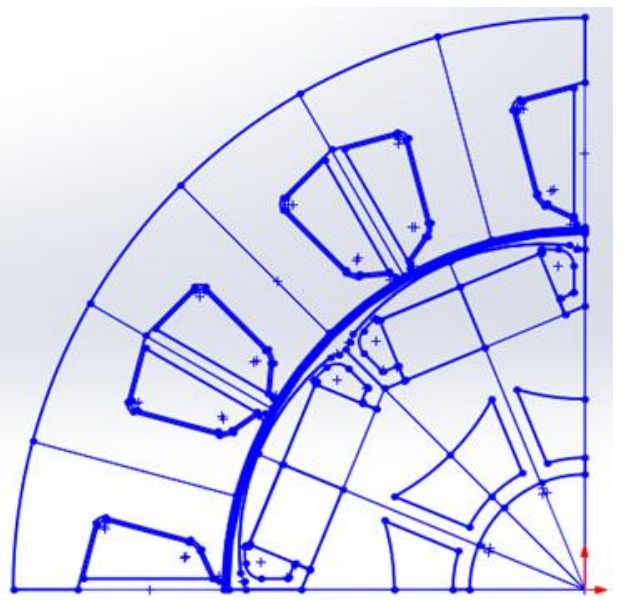

Gambar 1. Desain Menggunakan Solidwork

\subsection{Pengaturan Software Magnet Infolityca}

Pengaturan pada software magnet merupakan tahapan yang harus dilakukan sebelum memasukkan gambar desain dari solidwork ke dalam software magnet. Karena jika tidak dilakukan pengaturan terhadap software magnet maka parameter satuan yang digunakan pada gambar desain akan berubah dari satuan milimeter menjadi meter sebab parameter yang ada di jendela software magnet sebelum diatur adalah meter. Hal ini nantinya akan mempengaruhi hasil ouput dari rancangan generator tersebut. Gambar 2 dan 3 merupakan tampilan sebelum dan sesudah pengaturan tampilan pada software magnet.

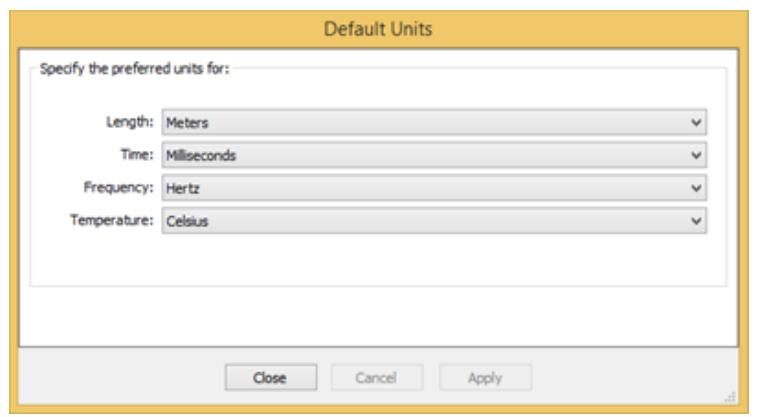

Gambar 2. Tampilan Sebelum Pengaturan

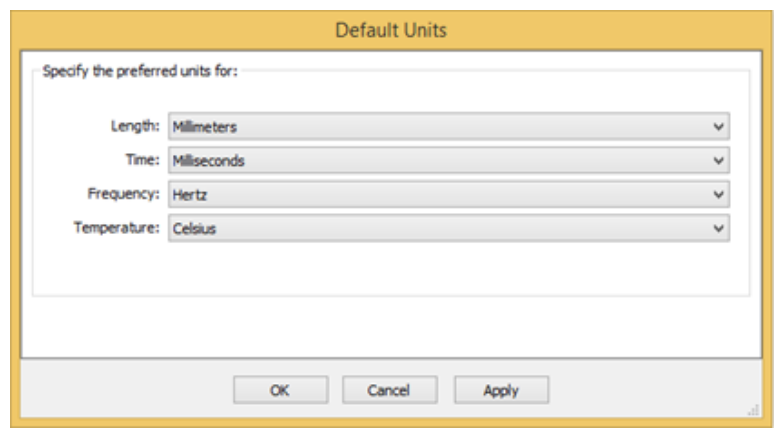

Gambar 3. Tampilan Setelah Pengaturan

\subsection{Inisialisasi dan desain geometri}

Inisialisasi dan desain geometri merupakan salah satu langkah untuk memberikan penamaan dan penentuan material yang digunakan terhadap komponen-komponen yang ada pada generator serta memberikan ukuran ketebalan pada setiap komponen tersebut. Inisialisasi dan desain geometri meliputi seluruh bagian komponen generator hingga tidak ada yang tidak terinisalisasi. Jika ada yang belum terinisialisasi, maka desain tidak akan dapat disimulasikan. Adapun komponen-komponen yang perlu diinisialisai untuk seperempat bagian, yaitu inisialisasi dan desain geometri terhadap stator, rotor, magnet, coil, airgap stator, rotor, airbox, dan shaft. Gambar 4 bagian generator yang perlu dilakukan inisialisasi. 


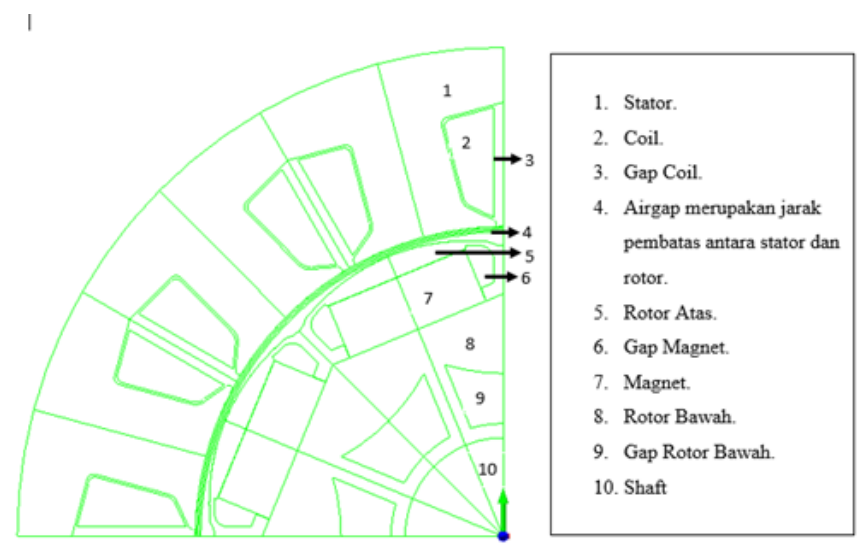

Gambar 4. Bagian Generator yang Dilakukan Inisialisasi

\subsection{Penentuan Mesh}

Software magnet Infolityca merupakan software yang berbasis Fenite Element Method (FEM). FEM merupakan metode yang digunakan untuk memecahkan masalah tentang medan elektromagnetik yang kompleks, sehingga mampu diselesaikan dengan model analisis terutama pada bagian yang terkait dengan sifat nonlinier bahan. Metode ini pada dasarnya mendiskritkan bagian penampang melintang mesin menjadi area-area atau volume kecil yang disebut fenite element atau mesh.

Pengaturan mesh pada setiap bagian berbeda misalnya saja pada bagian stator, rotor bawah, dan magnet menggunakan mesh $2 \mathrm{~mm}$, sedangkan untuk bagian rotor atas menggunakan mesh sebesar $1 \mathrm{~mm}$, dan pada bagian airgap menggunakan mesh sebesar 0,5 $\mathrm{mm}$. Adapun cara penentuan mesh berdasarkan perhitungan dan berdasarkan pengalaman ataupun kebiasaan para desainer motor maupun generator. Persamaan 1 dan Persamaan 2 digunakan untuk menentukan besarnya mesh.

$$
\begin{gathered}
\theta_{\text {mek }}=\frac{360}{k p k}(\text { derajat } / m s) \\
\theta_{\text {mesh }}=\frac{\theta_{\text {mek }}}{\sum \text { sampling data }}
\end{gathered}
$$

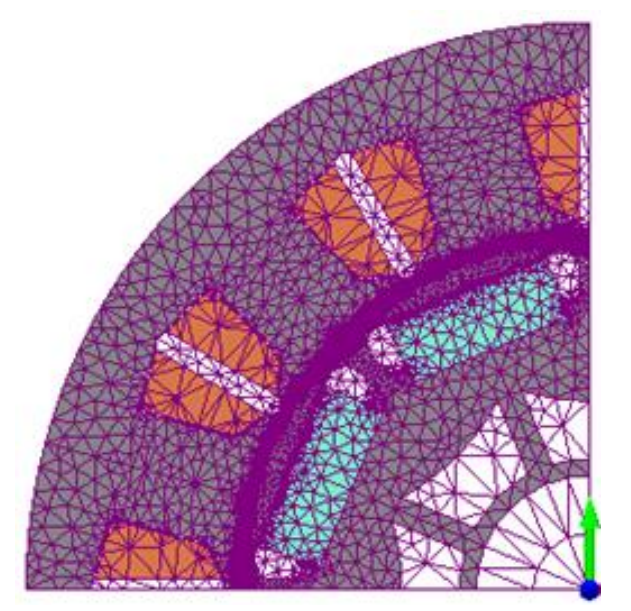

Gambar 5. Penentuan Mesh Pada 1/4 Desain

\subsection{Pemberian Lapisan Batas}

Lapisan batas merupakan sebuah tools pada software magnet Infolityca, dimana tools ini digunakan ketika mendesain generator $1 / 4$ ataupun $1 / 2$ bentuk, dari bentuk yang sepenuhnya (360) digunakan untuk mencerminkan kembali bagian dari generator tersebut seolah-olah pada bagian $1 / 4$ ataupun $1 / 2$ bagian lainnya masih ada bagian yang sama, sehingga desain motor 
mampu disimulasikan dengan memutar rotornya dengan sudut yang telah ditentukan. Gambar 6 merupakan pemberian lapisan batas pada bagian generator.

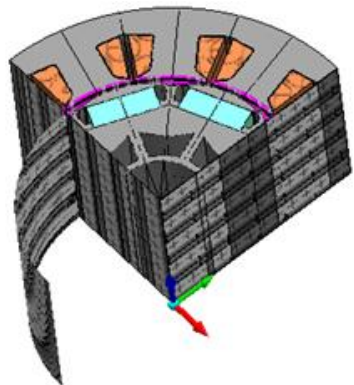

Gambar 6. Pemberian Lapisan Batas Pada 1/4 Desain

\subsection{Pembuatan Rangkaian}

Tahapan pembuatan rangkaian, merupakan tahapan untuk membuat rangkaian yang ada pada lilitan generator, karena setiap pengujian atau simulasi generator yang menggunakan software magnet Infolityca memiliki perbedaan rangkaian, baik untuk pengujian generator berbeban maupun generator tanpa beban. Gambar 7 dan 8 merupakan rangkaian tanpa beban serta rangkaian yang memiliki beban pada software magnet Infolityca.

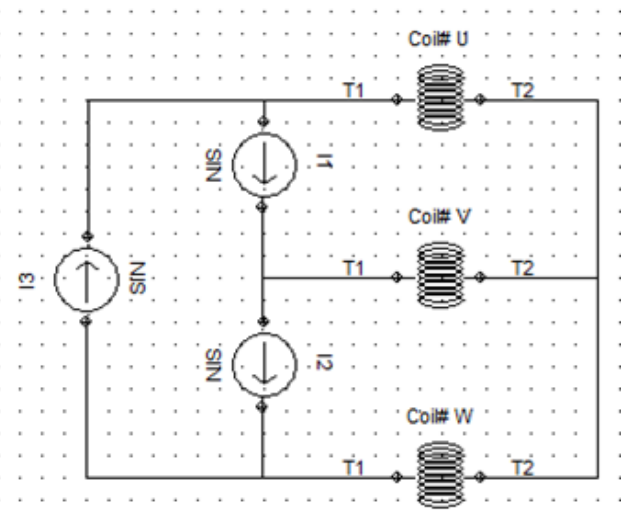

Gambar 7. Rangkaian Tanpa Beban

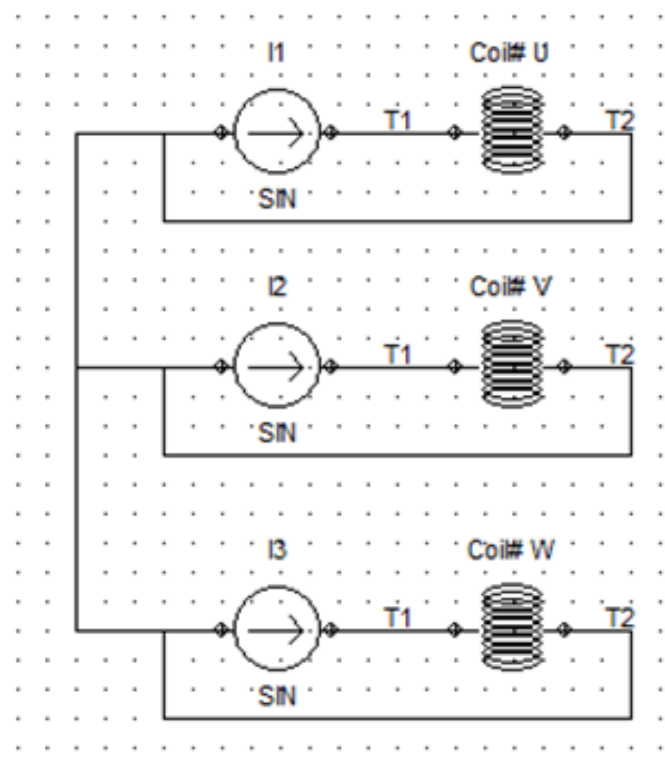

Gambar 8. Rangkaian Berbeban 


\subsection{Simulasi Model \\ 2.8.1 Memutar Rotor}

Sebelum melakukan simulasi dengan memutar rotor maka ada beberapa tahapan yang perlu dilakukan supaya rotor dapat berputar secara otomatis. Pertama memasukkan parameter angle dengan tipe nomor kemudian memasukkan nilai perubahan setiap sudutnya. Selanjutnya melakukan pemanggilan parameter angle tersebut pada parameter rotation angle dengan cara menuliskan \%Angle\%deg. Gambar 9 menunjukkan penulisan parameter angle, sedangkan Gambar 10 merupakan pemanggilan parameter angle.

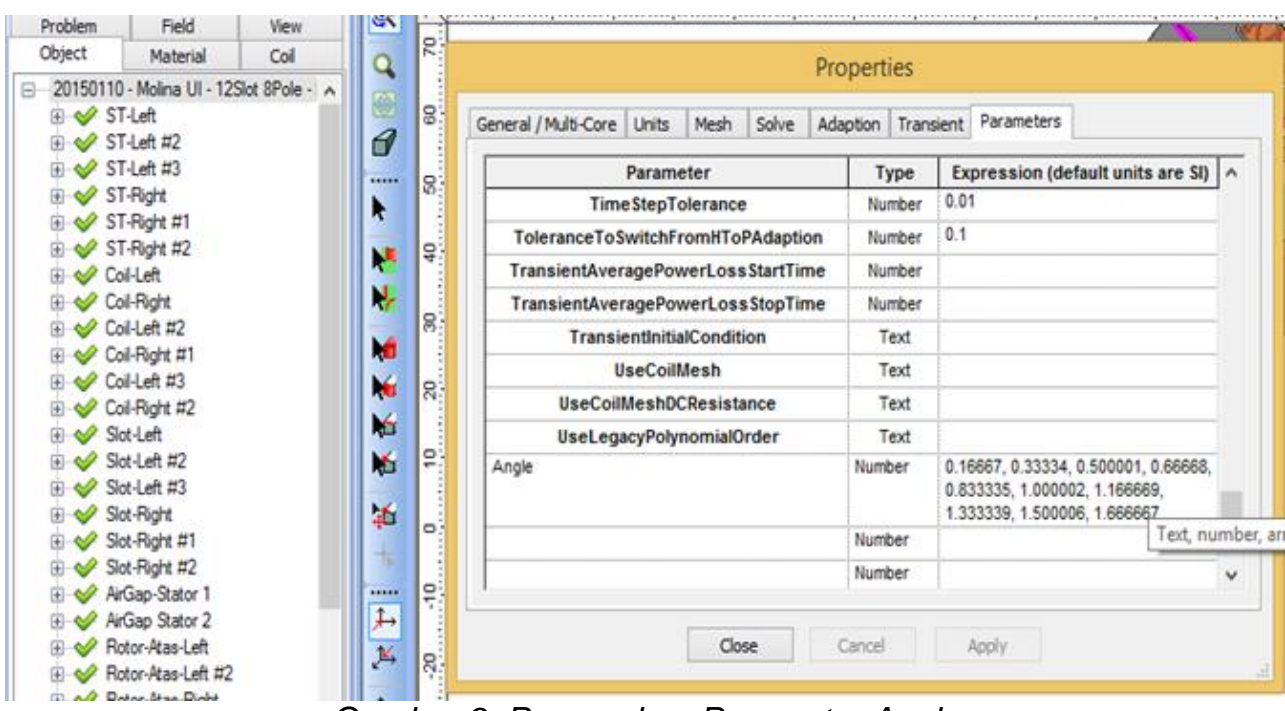

Gambar 9. Pemasukan Parameter Angle

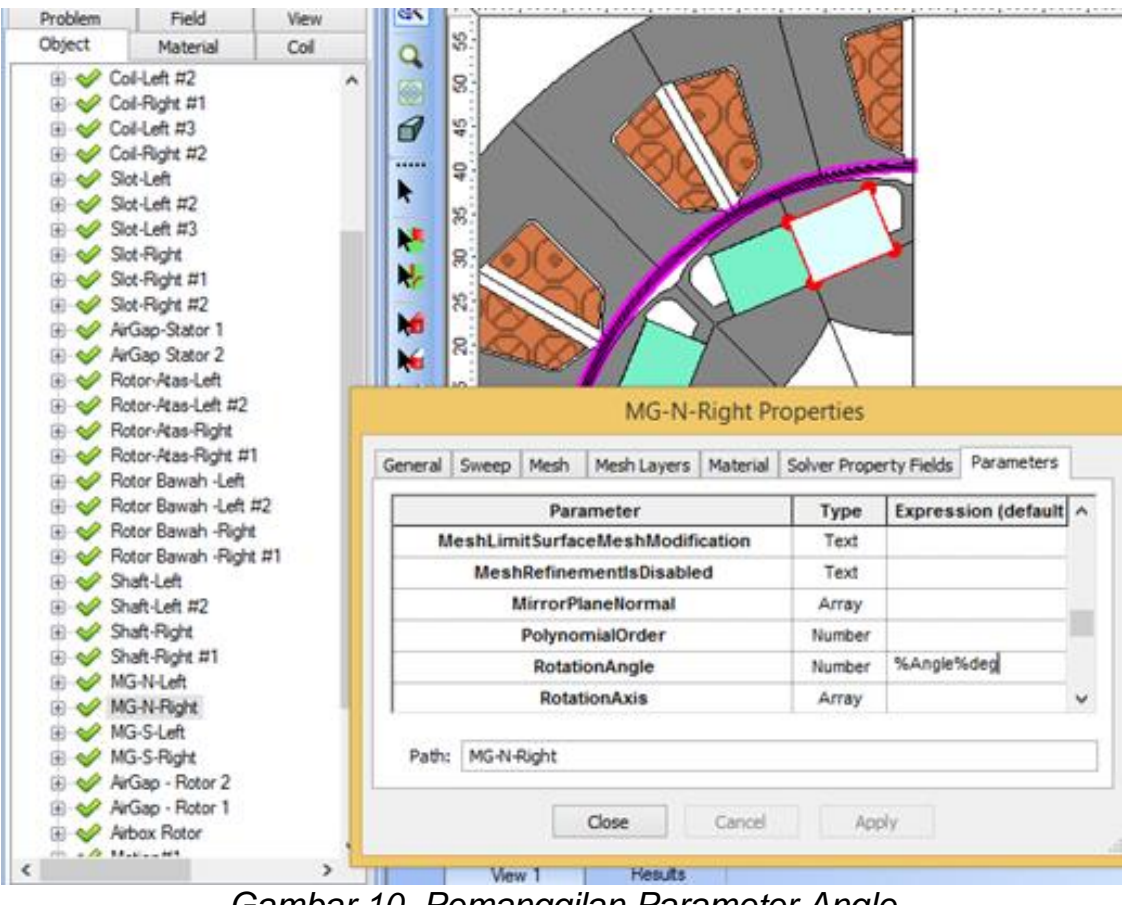

Gambar 10. Pemanggilan Parameter Angle

\subsubsection{Pengaturan Parameter Solve}

Pada tahap ini ada 2 parameter solve yang perlu diatur, pertama parameter solve options dan parameter set adaption options. Untuk parameter solve options yang diatur adalah nilai dari Max.Newton Iteration dan Newton Tolerance sedangkan untuk parameter set adaption option yang diatur adalah $h$-adaption dan tolerance. Gambar 11 merupakan pengaturan parameter solve options, sedangkan Gambar 12 adalah pengaturan set adaption option. 


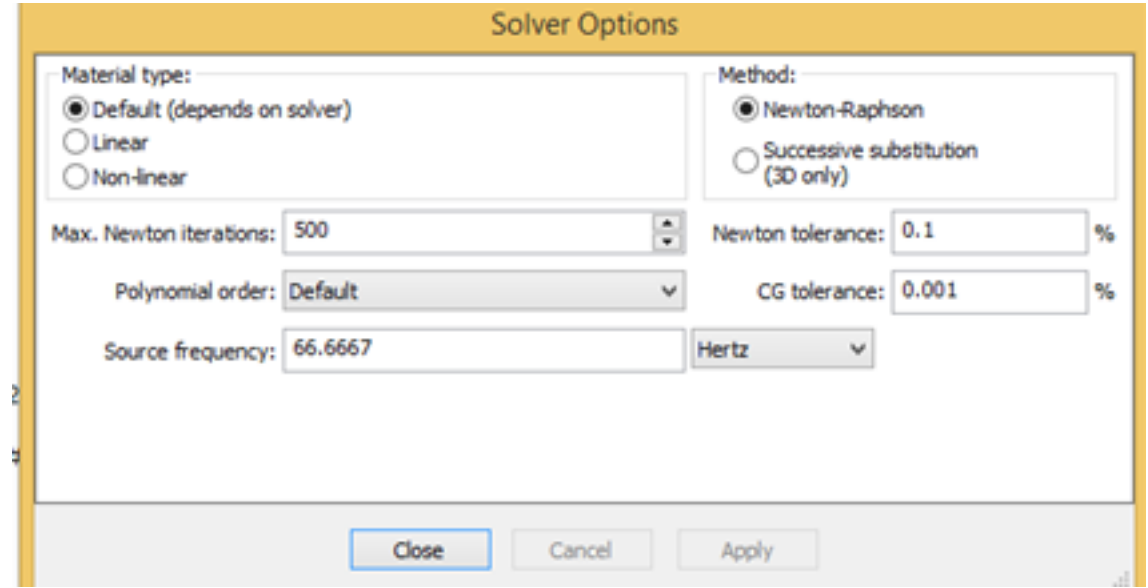

Gambar 11. Pengaturan Solve Options

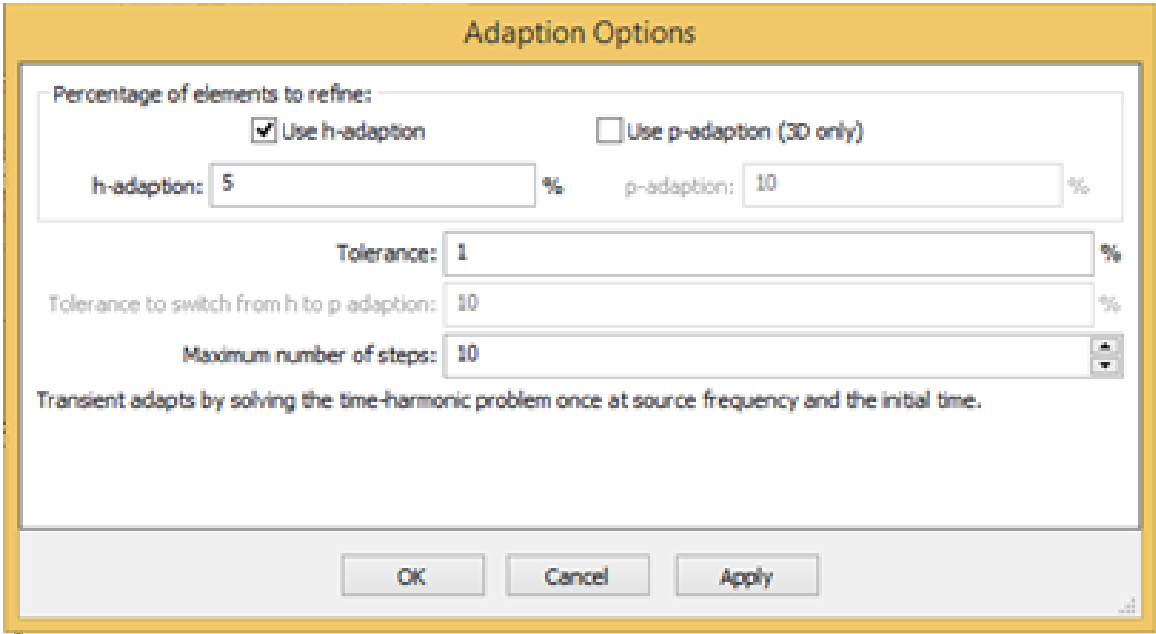

Gambar 12. Pengaturan Set Adaption Option

\subsection{Perhitungan Generator}

Persamaan 3 digunakan untuk menentukan sudut mekanik, sedangkan Persamaan 4 digunakan untuk menentukan sudut elektrik, dan Persamaan 5 untuk menentukan frekuensi.

$$
\begin{gathered}
\theta_{\text {mek }}=\frac{360}{k p k}(\text { derajat } / \mathrm{ms}) \\
\theta_{\text {Elek }}=\frac{\text { Pole }}{2} x \theta_{\text {Mek }} \\
F=\frac{1}{T}
\end{gathered}
$$

Saat menentukan frekuensi diperlukan nilai Amplitudo, Pada desain ini, rotor diputar setiap 1 derajat dengan waktu 0,16667 ms, maka untuk memutar 360 derajat dibutuhkan waktu $60 \mathrm{~ms}=0,06 \mathrm{~s}$, sehingga didapatkan nilai Amplitudo sebesar 0,06ms. Pada Persamaan 6 untuk menentukan waktu setiap 1 derajat, kemudian Persamaan 7 digunakan untuk menentukan kecepatan putar, dan Persamaan 8 digunakan untuk menentukan koefisien energi.

$$
\begin{gathered}
t_{\theta}=\frac{\theta_{\text {mek }}}{\Sigma \text { sampling data }} \\
\omega=2 . \pi \cdot f
\end{gathered}
$$




$$
K_{e}=\frac{V d c}{\omega}
$$

Berdasarkan Persamaan 3 sampai dengan Persamaan 8 didapatkan hasil perhitungan dalam Tabel 1.

Tabel 1. Hasil Perhitungan Generator

\begin{tabular}{cccc}
\hline No & Parameter & Nilai & Satuan \\
\hline 1 & Sudut Mekanik & 15 & Derajat \\
\hline 2 & Sudut Elektrik & 60 & Derajat \\
\hline 3 & Frekuensi $1 / 4$ Bagian & 16.6667 & $\mathrm{~Hz}$ \\
\hline 4 & Waktu Setiap 1 detik & 0.16667 & $\mathrm{Ms}$ \\
\hline 5 & Kecepatan Putar & 104.7 & $\mathrm{Rad} / \mathrm{s}$ \\
\hline 6 & Koefisien Energi & 0.2282 & - \\
\hline
\end{tabular}

\section{Hasil Penelitian dan Pembahasan}

Perancangan generator 100 watt yang telah dibuat dalam software elektromagnetik Infolityca kemudian disimulasi dengan menggunakan tools solve 2D dan data hasil simulasi diolah menggunakan software Microsoft Excel. Adapun data yang didapatkan dari pengolahan data tersebut, yaitu tegangan tiap coil, tegangan antar coil, tegangan input, bug EMF, dan kecepatan putar.

\subsection{Pengujian Generator Tanpa Beban Menggunakan 12 Lilitan}

Berdasarkan simulasi generator tanpa beban menggunakan 12 lilitan didapatkan hasil dari softawre magnet dan data hasil dari pengolahan data menggunakan Microsoft Excel dalam tabel 2.

Tabel 2. Hasil Simulasi Generator Tanpa Beban Menggunakan 12 Lilitan

\begin{tabular}{cccc}
\hline No & Parameter & Nilai & Satuan \\
\hline 1 & Tegangan Output & 21.65 & VDC \\
\hline 2 & Arus Output & 0 & $\mathrm{~A}$ \\
\hline 3 & Kecepatan Putar & 104.6667 & $\mathrm{Rad} / \mathrm{s}$ \\
\hline 4 & Frekuensi & 16.6667 & $\mathrm{~Hz}$ \\
\hline 5 & Koefisien Tegangan & 0.21 & $\mathrm{~V}$ \\
\hline 6 & Torsi & 0.00165 & $\mathrm{Nm}$ \\
\hline
\end{tabular}

Data hasil simulasi tanpa beban dalam Tabel 2 dapat dianalisis, ketika generator tanpa beban dengan menggunakan 12 lilitan tidak menghasilkan arus hal tersebut tidak lepas dari rangkaian yang telah dirancang sebelumnya, karena ketika generator tanpa beban pada rangkaian tersebut akan mengalirkan arus hanya pada sumber arus saja atau langsung mengalirkan pada ground karena rangkaian tersebut menggunakan hubungan star/wye.

\subsection{Pengujian Berbeban Menggunakan 12 Lilitan}

Berdasarkan simulasi generator berbeban menggunakan 12 lilitan didapatkan hasil, dari softawre magnet dan data hasil pengolahan data menggunakan Microsoft Excel dalam Tabel 3.

Tabel 3. Hasil Simulasi Generator Berbeban Menggunakan 12 Lilitan

\begin{tabular}{cccc}
\hline No & Parameter & Nilai & Satuan \\
\hline 1 & Tegangan Output & 23,89267 & Volt dc \\
\hline 2 & Arus Output & 5 & Ampere \\
\hline 3 & Kecepatan Putar & 104,6667 & Rad/s \\
\hline 4 & Frekuensi & 16.6667 & $\mathrm{~Hz}$ \\
\hline 5 & Koefisien Tegangan & 0,228158 & $\mathrm{Volt}$ \\
\hline 6 & Torsi & 0,238 & $\mathrm{Nm}$ \\
\hline
\end{tabular}

Data hasil simulasi dalam Tabel 3 dapat dianalisis, bahwa ketika generator berbeban menggunakan 12 lilitan menghasilkan arus hal tersebut tidak lepas dari rangkaian yang telah dirancang sebelumnya. Saat generator berbeban pada rangkaian tersebut akan mengalirkan 
arus dari sumber ke beban sehingga arus mampu dikeluarkan dan pada rangkaian tersebut juga menggunakan hubungan star/wye.

\section{Kesimpulan}

Setelah dilakukan proses perancangan dan pengujian maka dapat disimpulkan:

1. Cara perancangan generator harus melalui beberapa tahapan mulai dari pengumpulan, pendesainan menggunakan software solidwork, pendesainan dengan software magnet serta menganalisis menggunakan Microsoft Excel.

2. Tegangan output dalam perancangan generator 100 watt dipengaruhi oleh diameter, bahan material, ketebalan serta jumlah lilitan yang digunakan serta kecepatan putar generator tersebut.

3. Gap/jarak antara stator dan rotor harus dipertimbangkan serta diperhitungkan karena jarak tersebut akan mempengaruhi jumlah fluks yang mengalir dari stator ke rotor maupun sebaliknya.

4. Untuk menghasilkan arus, generator harus ada beban supaya arus dapat mengalir karena ada beda potensial.

\section{Daftar Notasi}

Notasi dapat diuraikan dengan keterangan sebagai berikut:

$F \quad=$ Frekuensi

$\theta_{\text {mek }} \quad=$ sudut mekanik

$\theta_{\text {Elek }}=$ Sudut Elektrik

$t_{\theta} \quad=$ Waktu Putar

$\omega \quad=$ Kecepatan Putar

Kpk = Kelipatan persekutuan terkecil dari Jumlah slot dan pole

\section{Referensi:}

[1] Wahyudi Dwi Pramono, Warindi, Ahmad Hidayat. "Perancangan Mini Generator 200 watt untuk Energi Angin Kecepatan Rendah." Prosiding Seminar Nasional Teknologi Industri dan Informatika (SNATIF), 2015; Vol. 2.

[2] Kenjō, Takashi, and Shigenobu Nagamori. "Permanent-magnet and brushless DC motors." Oxford University Press, USA, Vol. 18, 1985.

[3] Satriawan, Mirza. "Fisika Dasar." Universitas Gadjah Mada, 2012.

[4] Hendershot, James R., and Timothy John Eastham Miller. "Design of Brushless PermanentMagnet Motors." Magna Physics Pub., 1994.

[5] Fitzgerald, A. E., Kingsley, C., Umans, S. D., \& James, B. Electric machinery. Vol. 5. New York: McGraw-Hill. 2003

[6] Chapman, Stephen. Electric machinery fundamentals. Tata McGraw-Hill Education, 2005.

[7] A. E. Fitzgerald, Charles Kingsley., Jr, Stephen D. Umans, Ir. Djoko Achyanto Msc.EE. Mesin-Mesin Listrik. Jakarta: Erlangga. 1986. 
